\title{
味噌中のメラニン生成抑制物質の同定
}

間 和彦*・新本洋士** 小堀真珠子** ・津志田藤二郎 ${ }^{* *}$

\section{Purification and Identification of Melanogenesis Inhibitory Factors in Miso}

\author{
Kazuhiko AIDA*, Hiroshi SHINmoto**, Masuko KoBori* ${ }^{* *}$ and Tojiro TsushidA ${ }^{* *}$ \\ * Central Laboratory, Nippon Flour Mills Co., Ltd., 2114-2 Nurumizu, Atsugi-shi, Kanagawa 243-0033 \\ ** National Food Research Institute, the Ministry of Agriculture, Forestry and Fisheries, \\ 2-1-2, Kannondai, Tsukuba-shi, Ibaraki 305-8642
}

\begin{abstract}
In the previous paper, we reported that an extract from miso strongly suppressed melanogenesis of $\mathrm{B} 16 \mathrm{C} 7$ melanoma cells. In this paper, we purified two melanogenesis suppressing materials. The materials were identified to be linoleic acid and ethyl linoleate by mass spectrometric analysis. Synthesis of tyrosinase, a key enzyme on melanogenesis, of $\mathrm{B} 16 \mathrm{C} 7$ melanoma cells was strongly suppressed by addition of linoleic acid to a culture medium, whereas linoleic acid did not inhibit the activity of partially purified tyrosinase from B16C7 melanoma cells.
\end{abstract}

(Received Jun. 11, 1997 ; Accepted Dec. 1, 1997)

近年食品には栄養素としての働きのみならず，発癌や 老化を防止したり，血圧を調節するような生体調節機能 を持った成分が含まれていることが明らかにされてい るリ.このような食品の機能は 3 次機能と呼ばれている. 日本の伝統的発酵食品である味憩についても, 新しい生 体調節機能が明らかにされつつあり，味頜成分による放 射線傷害の防止作用, 血圧降下作用, 变異原性物質の不 活性化作用, コレステロール低下作用などの報告があ $3^{2)}$

筆者らは味㽞が有する高度の生体調節機能を解明する 一環として，マウスメラノーマ細胞を用い，味㗱のメラ ニン生成抑制作用について検討を行ってきた.メラニン は生体内にみられる褐色ないし黒色の色素の総称で, 皮 庙の色，毛髪の色を決定する色素である.メラニンの生 合成経路は詳しく研究されており、メラノサイトと呼ば れる色素細胞中のメラノッーム顆粒中で，チロシンがチ ロシナーゼによって酸化され，何段階るの酸化重合過程 を経て合成される。

筆者らは,これまでに味噌の熱水抽出画分およびエタ ノール抽出画分に，強いメラニン生成抑制作用があるこ

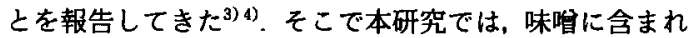
るメラニン生成抑制物質を単離精製し，味噌中の遊離り ノール酸が有効成分であることを見いだしたので報告す ろ.

\section{実 験 方 法}

\section{1. 味哈抽出物の調製}

中央味噌研究所より提供された麦味噌を試料として用 いた。味眳 1 重量に対し，エタノール4容量を加え，よ く摫拌後， $4^{\circ} \mathrm{C}$ で 16 時間静置して抽出を行った。混合液 を $10000 \mathrm{rpm}, 30$ 分間遠心し上清を得た. 上清を純水に 対して $4^{\circ} \mathrm{C} て ゙ 48$ 時間透析し，透析チューブ内に析出し た浮遊性不溶物を演過（東洋浣紙 No. 2) により分離し, エタノールに再溶解して回収した。

\section{2. 高速液体クロマトグラフィーによる味噌エタノー ル抽出物の分画 \\ エタノール抽出物をへキサン：エタノール（90:10）}

混液に溶解し, Intersil PREP-SIL カラム $(10 \times 250$ $\mathrm{mm}$, ジーエルサイエンス)に注入した. へキサン：エ夕 ノール $(90: 10)$ 混液, 流速 $2 \mathrm{ml} / \mathrm{min}$ で溶出し, 示差屈

*日本製粉株式会社中央研究所（厂243-0033 神奈川県厚木市温水 2114-2）

**農林水産省食品総合研究所（テ305-8642 茨城県つくば市観音台 2-1-2） 
折検出器で溶出物のモニターを行った，溶出画分は濃縮 後, ジメチルスルホキシド (DMSO) に溶解してメラニ ン生成抑制試験に用いた。

\section{3. 活性画分の復量分析}

クロマトグラフィーによって得た活性画分をグリセ ロールと混合し，日本電子 SX-101 型質量分析機を用い て FAB-MS 分析を行った. これによって得られたマス フラグメントイオンを解析し，分子量ならびに化学構造 を推定した。

\section{4. マウスメラノーマによるメラニン生成抑制試験}

マウス由来のメラニン高生産性 B 16 C 7 メラノーマ 細胞を用いた。 細胞は $10 \%$ 牛胎児血清 (FCS) を添加し たダベッコ変法最小必須培地 (DMEM) で継代培養し

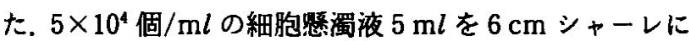
まきこみ, 24 時間前培養した，前培養後，培地を新鮮培 地に交換し，試料を添加した，48 時間培養後培地交換お よび試料添加を行い，さらに24時間培養した。

細胞はトリプシン処理により回収した．培地を吸引除 去し、トリプシン溶液 $(200 \mathrm{IU} / \mathrm{ml}) 0.5 \mathrm{ml}$ を加えて細胞 を剝離させた．直ちにトリプシンインヒビター液（50 $\mu \mathrm{g} / \mathrm{m} l) \quad 0.5 \mathrm{~m} l$ でトリブシンを不活性化させ，これに 4 $\mathrm{m} l$ のリン酸緩衝生理食塩水 (PBS) を加えて細胞を要濁 し、試験管に回収した. 細胞を $1500 \mathrm{rpm}$ で 10 分間遠心 沈殿させ，沈殿の色調を観察することによってメラニン 生成を判定した．また，細胞あたりのメラニン生成量算 出のため, 細胞数とメラニン含量を測定した. 回収した 細胞僖濁液のうち $1 \mathrm{~m} l$ を用いて Sysmex セルカウン ター（東亜医用電子）で細胞数を測定した. 残りの細胞 を遠心沈殿させ， 1 規定水酸化ナトリウム溶液で細胞を 溶解後, $475 \mathrm{~nm}$ の吸光度を测定し, あらかじめ作成し た標準メラニン（Sigma）の検量線からメラノーマのメ ラニン生成量を算出した だ 4).

水溶性試料はPBSに溶解し,フィルター隇菌 $(0.45$ $\mu \mathrm{m})$ して培地に添加した. 脂溶性試料は DMSO に溶解 し，そのまま添加した，培養液 $5 \mathrm{ml}$ あたり $20 \mu l$ までの DMSO の添加は細胞増殖，メラニン生成のいずれにも 影敕を与えなかったので，DMSOに溶解した試料の添 加量は $20 \mu l$ 以下とした。 また $20 \mu l$ の DMSO のみを添 加した培羔区を陰性対照とした。陽性対照としては，ア ルブチンおよびコウジ酸を用いだ）

5. チロシナーゼ活性直接阻害作用の测定

10\% FCS を含む DMEM で継代培養した B 16 C 7 細 胞 $5 \times 10^{7}$ 個を， $0.1 \%$ TritonX 100 を含む $0.1 \mathrm{M}$ リン酸

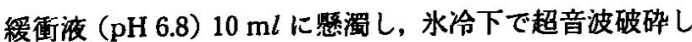

た，破砕液を $15000 \mathrm{rpm}$ で 20 分間遠心し，上清をチ口 シナーゼ粗酵素液とした。

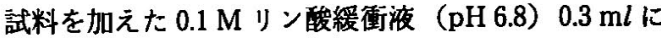
粗醅素液 $0.3 \mathrm{ml}$ を加えて $37^{\circ} \mathrm{C}$ で 10 分間プレインキュ ベーション後，基質として $0.15 \%$ L-DOPA 溶液を 0.3 $\mathrm{ml}$ 加えた. $37^{\circ} \mathrm{C}$ で 20 分間インキュベーションし， 475 $\mathrm{nm}$ の吸光度変化をチロシナーゼ活性とした4）被検物 質の終濃度は $33 \mu \mathrm{M}$ とした.

6. メラノーマ細胞内チロシナーゼ誘盖㧕制作用の測 定

メラーン生成抑制試験と同様に B 16 C 7 細胞に試料 （終濃度 $100 \mu \mathrm{M}$ ）を加えて 4 日間培養し，ハーベストし た細胞を，チロシナーゼ活性直接阻害作用の测定の項と 同様に破砕して粗醉素液とし，チロシナーゼ活性を測定 した.

\section{実 験 結 果}

\section{1. 味哈抽出物のメラニン生成抑制作用}

味噌からのメラーン生成抑制物質の抽出にはエ夕ノー ルを用いた．得られた抽出液から味眳に含まれる食塩を 除く目的で透析を行ったところ，浮遊性の不溶物が析出 した，不溶物を浧過して除去したところ，メラニン生成 抑制作用が完全に消失したことから、メラニン生成抑制 活性はこの不溶物中に存在すると考えられた.

マウスメラノーマB 16C 7 細胞を味㽞エタノール抽 出非透析性不溶画分とともに培養し, 細胞を回収して沈 殿させた。図1に示したように，1のコントロールでは 細胞内に黒いメラニンが生成していた，これに対し，28 $\mu \mathrm{g} / \mathrm{m} l$ の味㽞抽出画分を添加した 2 では, 細胞の明らか な淡色化が観察された.メラニン生成抑制物質として知 られているアルブチンを $50 \mu \mathrm{M}$ 添加して培養した 3 よ りも, 味㽞抽出物添加の方が, 淡色化が著しかった.

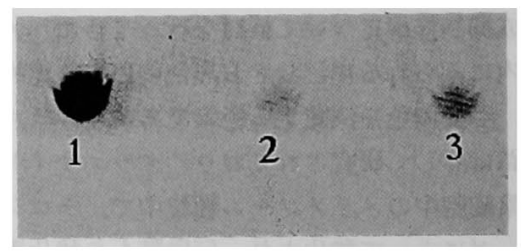

困 1 味咱エタノール抽出物とともに培養したB 16 C 7 細胞の淡色化

1, コントロール（添加物なし）

2 , 味眳エタノール抽出物 $(28 \mu \mathrm{g} / \mathrm{ml})$

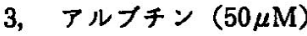


2. 高速液体クロマトグラフィーによる活性成分の分 画と同定

味㽞抽出物（上記の浮遊性不溶物）を高速液体クロマ トグラフィーで分画した．図 2 に示した 5 つの画分を集 め, B 16 C 7 細胞に添加して培養したところ，ピーク 2 およびビーク 4 に強いメラニン生成抑制活性か認められ た. いずれの画分も，薄層クロマトグラフィーでシング ルスポットを与えた (データ省略).

ピーク 2 およびピーク 4 の質量行析の結果を図 3 に示 した. ピーク 4 では， $\mathrm{m} / \mathrm{z} 281$ に親分子由来之考えられ るシグナルが検出された．したがって，この画分に含ま れる物質の分子量は 280 と考えられた。 また, $\mathrm{m} / \mathrm{z} 41$, $55 ， 67 ， 81 ， 95$ および 109 にフラグメントが得られ，さ らに親分子から水分子が引き抜かれた $\mathrm{m} / \mathrm{z} 263$ のフラ

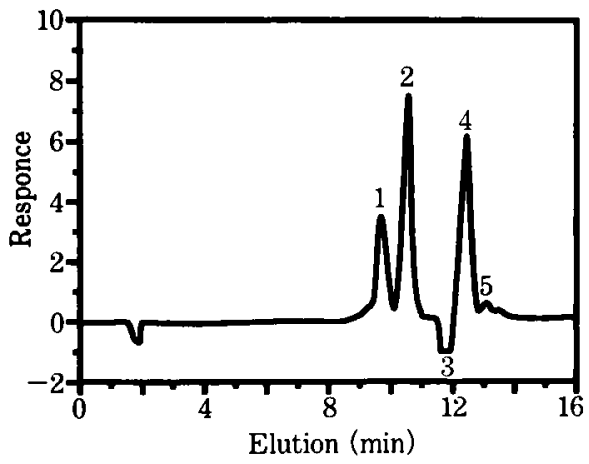

図 2 味㽞エタノール抽出画分の高速液体クロマト グラフィーによる分離

味啗エタノール抽出物をIntersil PREP-SIL カ ラムに注入し，へキサン：エタノール(90:10) 混旅で溶出させた。
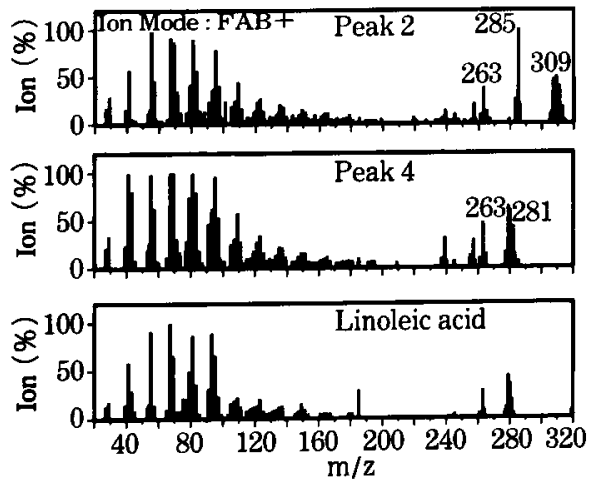

図 3 味哈中のメラニン生成抑制成分の質量分析
グメントあみられた．この質量分析パターンは，リノー ル酸標品の分析結果（図3下）とよく一致した. した がって，図2のピーク 4 はリノール酸であると推定され $た^{12)}$. 一方ピーク 2 に含まれる成分の分子量は, 質量分 析により $308(\mathrm{~m} / \mathrm{z} 309)$ と推定された.さらに，低分子 領域のフラグメントパターンがリノール酸とよく一致し たことから、この画分に溶出された物質はりノール酸エ チルエステルであると推定された，ピーク 2 の質量分析 においては， $\mathrm{m} / \mathrm{z} 285$ のフラグメントも検出された. こ れは上記 $\mathrm{m} / \mathrm{z} 263$ にナトリウムが結合したイオン（263 +23-1) であると推定された.

以上の結果より，高速液体クロマトグラフィーによっ て得られたメラニン生成抑制成分のうち，ピーク 4 はリ ノール酸, ピーク 2 はリノール酸エチルと同定された。

3. リノール酸のメラニン生成抑制作用

リノール酸の B 16 C 7 細胞の增殖およびメラニン生 成に対する作用，および比較のためにアルブチンを添加 した結果を図 4 に示した。 リノール酸 $100 \mu \mathrm{M}$ 添加にお いて, 細胞のメラニン生成は非添加の 2 割程度にまでに 抑制された. しかし，細胞増殖には影䍌がほとんどなく， リノール酸がメラニン生成を特異的に抑制していると考 えられた. アルブチンでも同様の作用が見られた。 リ ノール酸とアルブチンは同じ程度のメラニン生成抑制作 用を有していた.

\section{4. チロシナーゼ活性に対するリノール酸の作用}

B 16C 7 細胞から抽出したメラニン合成の鍵酵素であ るチロシナーゼの粗酵素の活性を、アルブチン,コウジ 酸，およびリノール酸存在下で湘定した，図 5 に示した ように,コゥジ酸はチロシナーゼ活性を強く阻害した.

また, アルブチンはわずかにチロシナーゼ活性を阻害し たのみであった：これに対して，リノール酸はチロシ ナーゼ活性をまったく阻害しなかった。

B 16C 7 細胞をアルブチン，コウジ酸，およびリノー ル酸存在下で培養し，それぞれの細胞中のチロシナーゼ 活性を測定した．図6に結果を示した．アルブチンとと もに培養した細胞では，細胞内のチロシナーゼ活性が著 しく低く、コントロールの 10 分の 1 まで低下していた. 同様にリノール酸にも強い作用が見られ, リノール酸と ともに培養した B 16 C 7 細胞内のチロシナーゼ活性は, コントロールの 4 分の 1 以下に低下していた.

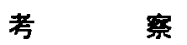

味喟のエタノール抽出物に, マゥスメラノーマ B $16 \mathrm{C}$ 7 細胞に対する強いメラニン生成抑制作用があり，この 

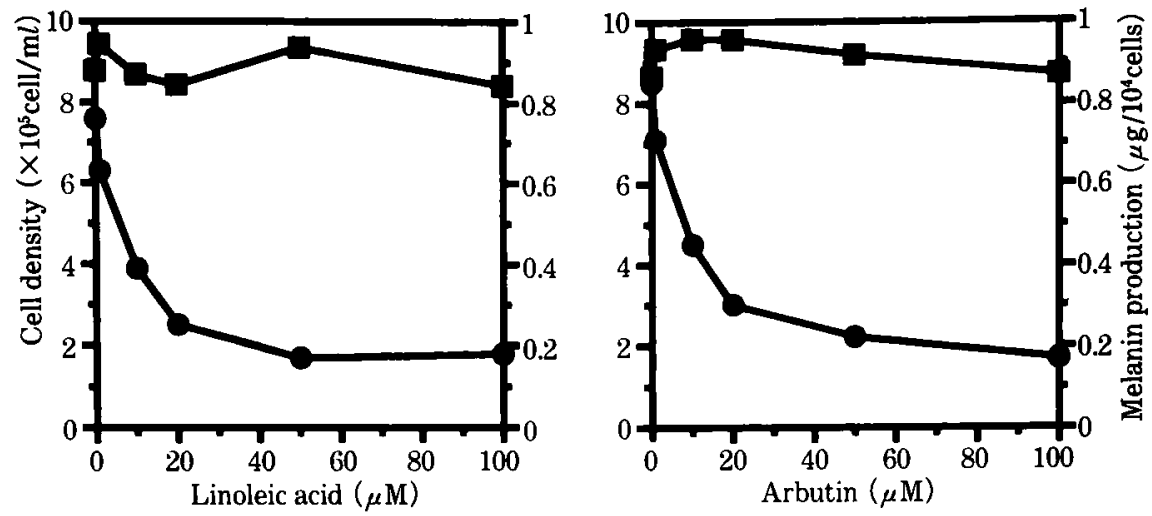

図 4 リノール酸およびアルブチンの B 16C7 細胞のメラニン生成抑制作用

口. 細胞数 ; ○,メラニン含量

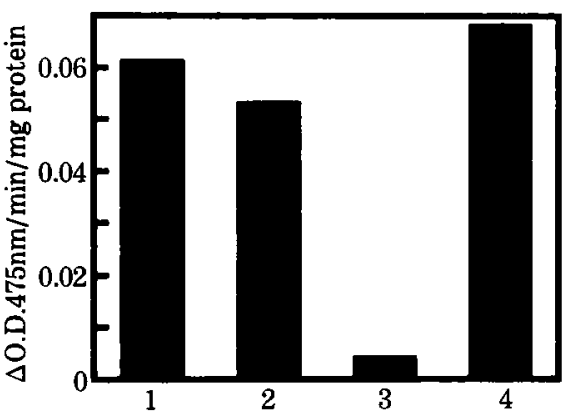

図 5 B 16C7 細胞から調製したチロシナーゼ粗醉 素標品に対するリノール酸の作用

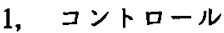
$2, \quad ア ル フ ゙ チ ン ~(33 \mu \mathrm{M})$
3 , コウジ酸 $(33 \mu \mathrm{M})$
4, リノール酸 $(33 \mu \mathrm{M})$

物質は非透析性で水に溶解しにくい性質を持っていた。 高速液体クロマトグラフィーによる分画と分画画分の質 量分析により，味㽞抽出物中のメラニン生成抑制物質と して,リノール酸およびリノール酸エチルが同定され た.

リノール酸はC $18: 2$ で表される不飽和脂肪酸であ る. 油脂中ではグリセリンと結合したトリグリセリドの 形で存在する．木内らは味咱熟成中の脂質の変化につい て詳しく検討し，大豆中に含まれるトリグリセリドがリ パーゼにより分解され，遊離脂肪酸が生成することを報 告している7，木内らによれば，大豆中では遊離脂肪酸 は全脂質中のわずか $2.3 \%$ であるが，熟成した味噌に

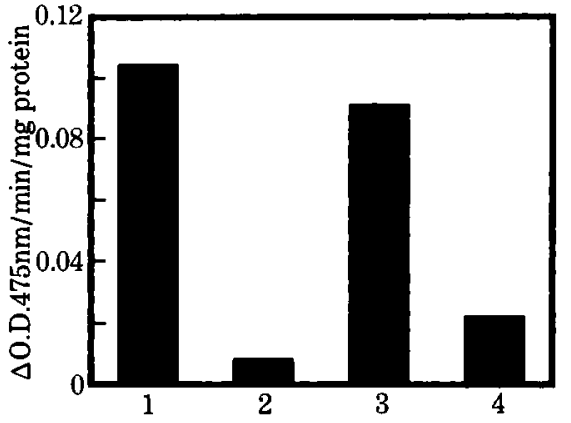

図 6 リノール酸ととすに培養した B $16 \mathrm{C} 7$ 細胞内 のチロシナーゼ活性

1, コントロール

$2, \quad$ アルブチン $(100 \mu \mathrm{M})$

3, コウシ酸 $(100 \mu \mathrm{M})$

4, リノール酸 $(100 \mu \mathrm{M})$

よっては，遊離脂肪酸の割合が全脂質の $58 \%$ にも達す る.またこの味噌試料では遊離脂肪酸の 6 割がリノール 酸を含むC $18: 2$ の脂肪酸であり，熟成した豆味㽞の場 合，遊離りノール酸含量は味咱重量の $3 \%$ に達すると計 算される．したがって，味哈は遊離リノ一ル酸の豊富な 食品であると言える.

今回，筆者らは味眳に含まれるメラニン生成抑制物質 がリノール酸およびりノール酸エチルであることを示し た.リノール酸のメラニン生成抑制作用については，す

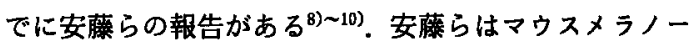
マおよび茶色モルモット皮席を用い，リノール酸がメラ ニン生成を強く抑制することを報告している，本研究で 
は,リノール酸は，B 16 C 7 細胞内に存在するチロシ ナーゼに対して直接醉素活性阻害作用を持つのではな く, 細胞内でチロシナーゼが誘導合成されるのを調節し ていると考えられた. 今後, チロシナーゼ mRNAの転 写レベルでの検討が必要と考えられる.

リノール酸を含むトリグリセリドの摄取は, 血中コレ ステロールを低下させるなどの有用な作用を持つことか ら²，一時はリノール酸のリッチな油脂に人気が集まっ た. しかしながらその後，リノール酸のようなn 6 系脂 肪酸はアラキドン酸系の炎症メディエータの原料となる ことから、リノール酸大量摄取はアレルギーなどを増悪 させる原因のように考えられるようになった．現在では $\alpha$ リノレン酸のような n 3 系不飽和脂肪酸との摄取心゙ラ ンスが重要であると考えられている(1)

安藤らはリノール酸をモルモットの皮庙に筀布するこ とによって，紫外線による日焼けを防ぐことができるこ とを報告している．本報告では味㽞中の遊離リノール酸 にメラニン生成抑制作用があることを明らかにしたが， これをもって味哈汁を飲むことが美白につながるという 直接の証执にはならない，また，トリグリセリドとして 摂取したリノール酸と，遊離リノール酸として摄取した あのとの間に，消化吸収過程での差異があるか否かは明 らかではない. したがって，味哈中の遊離脂肪酸の消化 管内での消長，および経口摄取された遊離リノール酸が 美白作用を持つか否かを今後検討する必要がある.

\section{要 約}

味㽞に含まれるメラニン生成抑制物質として,リノー ル酸およびリノール酸エチルが同定された。 リノール酸 は, メラノーマのチロシナーゼに対して直接酵素活性阻 害作用を持つのではなく, 細胞内でチロシナーゼが誘導 されるのを調節していると考えられた。
本研究の遂行にあたり、ご援助いただきました中央味 咱研究可に樑謝いたします. 本研究の概要は第 5 回日本 動物細胞工学会大会 (平成 7 年 7 月，山形) にて報告し た.

\section{文献}

1）津志田藤二郎 : Fragnance Journal, 1994-7, 14 (1994).

2）みそサイエンス最前線，みそ健康づくり委員会編 (1995)

3）實山安英・新本洋士・小堀真珠子・津志田藤二 郎・原和毅：味噌の科学と技術，43，68 (1995)

4）實山安英 - 新本洋士 ・ 小堀真珠子 - 津志田藤二 郎・篠原和毅 : 食工誌，43，712（1996）.

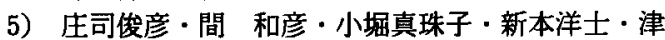
志田藤二郎 : 組織培養, 21，293 (1995).

6) Maeda, K. and Fukuda, M. : J. Soc. Cosmet. Chem., 42, 361 (1991).

7) Kiuchi, K., Oнta, T. and EBine, H. : Nippon Shokuhin Kogyo Gakkaishi, 23, 455 (1976).

8) ANDO, H., OKA, M., ICHIHASHI, M. and Mishima, Y. : Pigment Cell Res., 3, 200 (1990).

9）安藤秀哉・橋本 晃・政本幸三・市橋正光 - 三島 豊 : J. Soc. Cosmet. Chem. Jpn., 27, 415 (1993).

10) ANDo, H., ITOH, A., Mishima, Y. and IchinashI, M. : J. Cell Physiol., 163, 608 (1995).

11) Mayatepek, E., Paul, K., Leichsenring, M., Pfisterer, M., Wagner, D., Domann, M., SonNATAG, H.G. and BREMER, H.J. : Infection, 22, 106 (1994).

12）津志田藤二郎 - 村井敏信 - 大森正司 - 岡本順子 : 農化, 61，817 (1987).

(平成 9 年 6 月 11 日受付, 平成 9 年 12 月 1 日受理) 